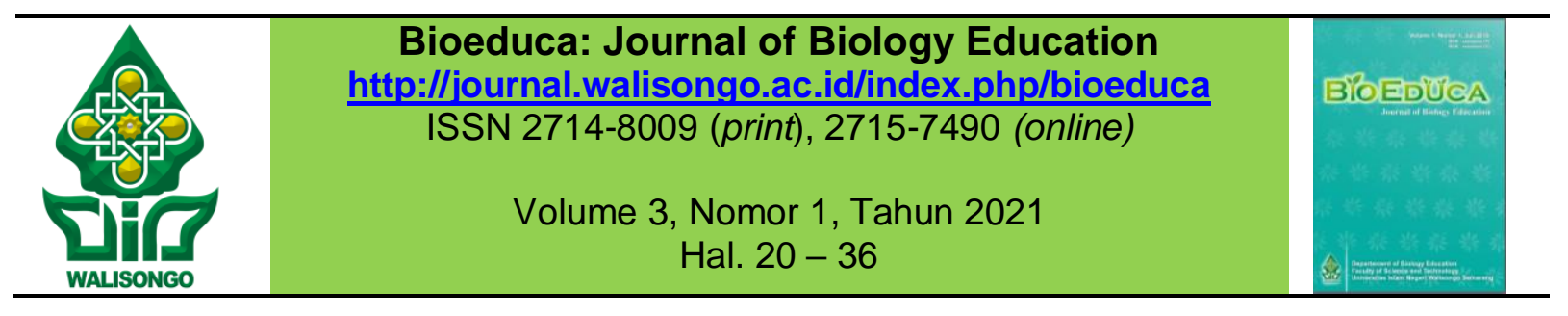

\title{
Studi Literatur Pengaruh Group Investigation terhadap Berpikir Kritis dan Aktivitas Lisan Siswa
}

\author{
Hirnanda Agustiawan ${ }^{1 *}$, Hani Irawati ${ }^{2}$ \\ ${ }^{1,2}$ Pendidikan Biologi, Universitas Ahmad Dahlan \\ *Email: hirnanda1600008147@webmail.co.id
}

\begin{tabular}{|c|c|}
\hline Informasi Artikel & ABSTRAK \\
\hline $\begin{array}{l}\text { Submit: } 19-10-2020 \\
\text { Diterima: } 31-03-2021 \\
\text { Dipublikasikan: } 31-03-2021\end{array}$ & $\begin{array}{l}\text { Pembelajaran abad } 21 \text { mengarahkan siswa untuk merumuskan } \\
\text { masalah dan menekan kerjasama dalam kelompok agar mampu } \\
\text { berpikir kritis dan komunikatif. Pembelajaran yang dilakukan guru } \\
\text { masih kurang melibatkan peran aktif siswa sehingga rasa ingin } \\
\text { tahu dan kamampuan bertanya siswa menjadi rendah. Tujuan } \\
\text { penelitian ini untuk mengetahui pengaruh model pembelajaran } \\
\text { group investigastion (GI) terhadap kemampuan berpikir kritis dan } \\
\text { kemampuan aktivitas lisan siswa berdasarkan hasil studi literatur. } \\
\text { Jenis penelitian ini adalah penelitian literature review dengan } \\
\text { desain penelitian narrative review. Artikel diperoleh } 34 \text { dilakukan } \\
\text { validasi. Hasil penelitian menunjukan bahwa studi literatur } \\
\text { pengaruh model pembelajaran group investigation (Gl) terhadap } \\
\text { kemampuan berpikir kritis dan aktivitas lisan siswa pada materi } \\
\text { biologi yaitu, terdapat pengaruh model group investigation (GI) } \\
\text { terhadap kemampuan berpikir kritis siswa pada materi biologi dan } \\
\text { terdapat pengaruh model group investigation (GI) terhadap } \\
\text { aktivitas lisan siswa } \\
\text { Kata kunci: aktivitas lisan; berpikir kritis; group investigation; } \\
\text { narrative review. }\end{array}$ \\
\hline Penerbit & ABSTRACT \\
\hline $\begin{array}{l}\text { Program Studi Pendidikan } \\
\text { Biologi, Fakultas Sains dan } \\
\text { Teknologi, UIN Walisongo } \\
\text { Semarang }\end{array}$ & $\begin{array}{l}\text { The 21st century learning directs students to formulate problems } \\
\text { and suppress cooperation in groups to be able to think critically } \\
\text { and communicatively. The learning carried out by the teacher still } \\
\text { does not involve the active role of students so that the curiosity } \\
\text { and ability of students to ask questions is low. The purpose of this } \\
\text { study was to determine the effect of the group investigation (Gl) } \\
\text { learning model on students' critical thinking skills and oral activity } \\
\text { abilities based on the results of a literature study. This type of } \\
\text { research is a literature review study with a narrative review } \\
\text { research design. Articles obtained were } 34 \text { validated. The results } \\
\text { showed that the study of the literature on the effect of the group } \\
\text { investigation (Gl) learning model on students 'critical thinking } \\
\text { abilities and oral activity on biology material, namely, there was } \\
\text { an effect of the group investigation (Gl) model on students' critical } \\
\text { thinking abilities in biology material and there was an effect of the } \\
\text { group investigation model ( Gl) on students' oral activities. } \\
\text { Keywords: critical thinking; group investigation (Gl); oral activity; } \\
\text { narrative review. }\end{array}$ \\
\hline
\end{tabular}

Copyright (C2021, Bioeduca: Journal of Biology Education 


\section{PENDAHULUAN}

Pembelajaran abad 21 bertujuan mampu membuat siswa menguasai kemampuan berpikir kritis, berkomunikasi, berkolaborasi dan kreativitas atau berinovasi (Wijaya, Sudjimat, dan Nyoto, 2016). Pembelajaran abad 21 ini mengarahkan siswa untuk merumuskan masalah, jadi tidak hanya mampu untuk menyelesaikan masalah saja, tetapi pembelajarannya menekankan pada kerjasama dan kolaborasi dalam menyelesaikan masalah. Menurut Wijaya et al., (2016) hal ini perlu adanya kemampuan berpikir kritis dan kemampuan berkomunikasi siswa dalam mengoptimalkan pembelajaran abad 21. Menurut Hapsari et al., (2012) terdapat beberapa temuan dari hasil observasi dalam pembelajaran biologi yaitu kurang melibatkan peran aktif siswa, hal ini akan membuat siswa kesulitan dalam proses pengorganisasian materi pada mata pelajaran biologi. Selain itu pembelajaran yang didominasi dengan ceramah dari guru dan siswa hanya mendengarkan saja. Hal ini akan membuat rasa ingin tahu siswa berkurang dan membuat rendah dalam kemampuan berpikir kritis.

Kemampuan abad 21 selain berpikir kritis yaitu kemampuan berkomunikasi. Kemampuan berkomunikasi bisa dilakukan secara lisan maupun tulisan, namun dalam penelitian ini difokuskan pada berkomuni secara lisan. Berkomunikasi scara lisan merupakan indikator dari aktivitas lisan (oral activity) siswa. Menurut Winarni (2016) menyebutkan bahwa aktivitas lisan siswa dalam pembelajaran diketahui masih rendah. Hal tersebut ditunjukan dari kamampuan bertanya siswa dalam pembelajaran yang sedikit bertanya dikarenakan guru lebih mendominasi selama pembelajaran. Guru lebih banyak menghabiskan waktu dengan menjelaskan materi, sehingga siswa kurang diberikan kesempatan untuk mengemukakan pendapat dan bertanya.

Keterampilan berpikir kritis dan aktivias lisan siswa memerlukan suatu model pembelajaran yang berpengaruh terhadap kemampuan berpikir kritis dan aktivias lisan siswa. Salah satu model pembelajaran yaitu model pembelajaran group investigation (Gl). Model pembelajaran group investigation (Gl) merupakan model pembelajaran kooperatif yang dapat membimbing siswa mendefinisikan masalah dan mengeksplorasi masalah. Selain itu membimbing siswa mengumpulkan data yang relevan, menguji hipotesis. Sehingga model ini melatih siswa membangun kemampuan berpikir secara kritis. Serta melatih siswa untuk menyelesaikan permasalahan (Wijayanti et al., 2013). Menurut Asokawati et al., (2018) langkah pembelajaran group investigation (Gl) mampu mengaktifkan siswa dalam proses pembelajaran. Seperti aktif bertanya dan menyampaikan pendapat. Model pembelajaran ini menekankan siswa melakukan akvitas lisan. Seperti berkomunikasi untuk bertukar informasi sehingga mampu menyelesaikan masalah. Menurut Nurdihidaya (2015) manfaat model pembelajaran group inestigation (GI) terhadap aktivitas lisan siswa yaitu pembelajaran dapat dibentuk secara berkelompok, sehingga setiap kelompok mendapatkan sub topik berbeda, hal ini akan memungkinkan terjadinya interaksi dan kerjasam dalam kelompok, sehingga aktivitas siswa seperti berkomunikasi, menanya dan menjawab dapat terlaksana. 
Penerapan model pembelajaran group investigation (GI) diterapkan pada pembelajaran biologi. Pembelajaran biologi memiliki materi yang abstrak (Murdiyani, 2012). Materi biologi yang abstrak lebih baik dengan pembelajaran yang kontekstual (Insyasiska et al., 2015). Sehingga memungkinkan siswa memahami materi biologi tersebut. Selain itu model pembelajaran group inestigation (Gl) mampu mengaktifkan aktivitas siswa. Salah satunya aktivitas lisan dalam pembelajaran. Sehingga siswa dapat berkomunikasi dan menyelesaikan permaslahan pada materi biologi. Kemudian materi biologi yang abstrak membutuhkan kemampuan berpikir kritis. Sehingga siswa tidak mengalami miskonsepsi materi biologi.

Tujuan penelitian ini yaitu mengetahuai pengaruh model pembelajaran group investigation (GI) terhadap kemampuan berpikir kritis dan aktivitas lisan siswa pada materi biologi berdasarkan studi literatur. Sehingga penelitian ini berjudul "studi literatur pengaruh model pembelajaran group investigation (Gl) terhadap kemampuan berpikir kritis dan aktivitas lisan siswa pada materi biologi".

\section{METODE PENELITIAN}

Jenis penelitian ini menggunakan jenis penelitian studi literatur. Studi literatur ialah pemeriksaan sistematis dengan tujuan mengetahui suatu topik tertentu yang dikaji secara ilmiah dengan menggunakan berbagai macam literatur (Efron \& Ravid,2019). Desain penelitian studi literatur pada penelitian ini menggunakan narrative review. Menurut Wang et al., (2015) narrative review berkaitan dengan merangkum, menjelaskan dan menginterprestasikan bukti. Mengenai sebuah topik dengan menggunakan bukti-bukti kualitatif. Narative review juga desain penelitian yang melakukan ulasan ulang. Hal tersebut dengan menganalisis secara komprehensif, objektif dan kritis.

Prosedur pencarian literature dilakukan sebagai berikut:

a. Mengunjungi beberapa situs sesuai dengan ketetapan yang telah ada, yaitu sebagai berikut :

Jurnal internasional yang didapatkan dari https://doaj.org, https://eric.ed.gov. Jurnal nasional terakreditasi yang didapatkan dari https://www.sinta.ristekbkrin.com. Jurnal nasional belum tekareditasi yang didapatkan dari https://www.garuda.ristekbkrin.com dan https://www.scholar.google.co.id. Prosiding yang didapatkan dari https://www.scholar.google.co.id. Repository berupa skripsi/thesis/disertasi yang didapatkan dari https://www.rama.ristekbkrin.co.id.

b. Memasukan kata kunci di kotak pencarian, namun setiap pemilihan artikel yang hendak dicari, memiliki perbedaan cara memilihnya yang dijabarkan sebagai berikut :

1) Jurnal internasional

Pada https://doaj.org dan https://eric.ed.gov kata kunci yang digunakan pada kotak pencarian yaitu "group investigation" kemudian dilakukan filter dengan mengklik "artikel penelitian", lalu cari artikel yang ingin di dapatkan. Jurnal nasional terakreditasi. 
a) Melakukan filter di kotak pencarian dengan memilih "Pendidikan IPA / Pembelajaran / Pendidikan Biologi".

b) Membuka satu persatu jurnal yang ditemukan, kemudaian klik website dan akan menuju ke website jurnal yang dikehendaki.

c) Melakukan pencarian artikel dengan menggunakan kata kunci yaitu "group investigation" pada kotak pencarian di website jurnal terkait.

2) Jurnal nasional belum terakreditasi, Prosiding

Menuliskan langsung di kotak pencarian dengan kata kunci yaitu pengaruh group investigasi "berpikir kritis"/ "oral activity" / "materi biologi".

3) Repostory

Pencarian dilakukan dengan memasukan kata kunci "group investigation" pada kotak pencarian. Setelah artikel (skripsi, thesis, disertasi) muncul pada laman web, pilih artikel yang diinginkan dengan menysuaikan dengan variabel yang diinginkan.

Validasi Kualitas Literatur

Menurut Saifudin \& Ma'rifah (2020) menyebutkan bahawa ketentuan kualitas literatur didasarkan/dipertimbangkan pada 4 hal, yaitu:

a. Kredibilitas sumber artikel yang berasal dari journal Internasional, jurnal nasional terakreditasi, jurnal nasional belum terakreditasi, Prosiding dan Repository.

b. Kulitas penyajian data dan pembahasan

c. Kecukupan data untuk dilakukan analisis

d. Referensi Up to update (10 tahun terakhir)

Validasi dilakukan oleh peneliti dan validasi ahli yaitu dosen pembimbing skripsi. Hasil dari validasi tersebut didasarkan pada 4 kreteria validasi kualitas literature. Jika artikel tersebut memenuhi suatu kreteria maka akan dibeikan tanda centang $(\sqrt{ })$ pada kolom tersebut. Penetuan hasil artikel ditentukan jika memenuhi 4 kreteria, maka akan diberikan tanda centang $(\sqrt{ })$ pada kolom hasil sebagai bukti bahwa artikel layak digunakan untuk dilakukan penelitian. Berdasarkan hal tersebut dapat diketahui hasil validasi kualitas literatur sebagai berikut:

Tabel 1. Hasil Validasi Kulaitas Literatur

\begin{tabular}{|c|c|c|c|c|c|c|c|c|c|}
\hline No. & $\begin{array}{c}\text { Nama } \\
\text { Penulis }\end{array}$ & Tahun & Judul & $\begin{array}{c}\text { Sumber } \\
\text { Artikel }\end{array}$ & $\begin{array}{l}\text { Bidang } \\
\text { Kajian }\end{array}$ & A B & C & D & Hasil \\
\hline \multicolumn{10}{|c|}{ Jurnal Internasional } \\
\hline 1. & $\begin{array}{l}\text { Elen Dining } \\
\text { Riani } \\
\text { Enda } \\
\text { Peniati } \\
\text { Supriyanto }\end{array}$ & 2017 & $\begin{array}{lr}\text { Penerapan } & \text { Model } \\
\text { Group Investigation } \\
\text { Terhadap } & \\
\text { Kemampuan } & \\
\text { Bertanya } & \text { Siswa } \\
\text { Materi } \quad \text { Sistem } \\
\text { Regulasi }\end{array}$ & $\begin{array}{l}\text { Unnes } \\
\text { Sceice } \\
\text { Education } \\
\text { Journal }\end{array}$ & $\begin{array}{c}\text { Aktivitias } \\
\text { lisan }\end{array}$ & $\sqrt{ } \sqrt{ }$ & $\sqrt{ }$ & $\sqrt{ }$ & $\sqrt{ }$ \\
\hline 2. & $\begin{array}{l}\text { E. Rosiani, } \\
\text { Parmin, M } \\
\text { Taufiq }\end{array}$ & 2020 & $\begin{array}{l}\text { Cooperative } \\
\text { learning model of } \\
\text { group investigation } \\
\text { type on students' }\end{array}$ & $\begin{array}{l}\text { Unnes } \\
\text { Sceince } \\
\text { Education }\end{array}$ & $\begin{array}{c}\text { Berpikir } \\
\text { Kritis }\end{array}$ & $\sqrt{ } \sqrt{ }$ & $\sqrt{ }$ & $\sqrt{ }$ & $\sqrt{ }$ \\
\hline
\end{tabular}




\begin{tabular}{|c|c|c|c|c|c|c|c|}
\hline No. & $\begin{array}{c}\text { Nama } \\
\text { Penulis }\end{array}$ & Tahun & Judul & $\begin{array}{c}\text { Sumber } \\
\text { Artikel }\end{array}$ & $\begin{array}{c}\text { Bidang } \\
\text { Kajian }\end{array}$ & A B C D & Hasil \\
\hline 3. & $\begin{array}{l}\text { I Wayan } \\
\text { santyasa, } \\
\text { I Nyoman } \\
\text { Kanca, } \\
\text { I Wayan } \\
\text { sukra } \\
\text { Warpala, } \\
\text { I Komang } \\
\text { Sudarna }\end{array}$ & 2019 & $\begin{array}{l}\text { critical thinking skill } \\
\text { and scientific } \\
\text { comunication skills } \\
\text { Group } \\
\text { Investigationdan } \\
\text { Explicit Learning } \\
\text { Models In Learning } \\
\text { Physics at Senior } \\
\text { High Schools }\end{array}$ & $\begin{array}{l}\text { JPPPF : } \\
\text { Jurnal } \\
\text { penelitian } \\
\text { dan } \\
\text { pengemba- } \\
\text { ngan } \\
\text { pendidikan } \\
\text { fisika }\end{array}$ & $\begin{array}{c}\text { Berpikir } \\
\text { Kritis }\end{array}$ & $\sqrt{ } \sqrt{ } \sqrt{ } \sqrt{ }$ & $\sqrt{ }$ \\
\hline No. & $\begin{array}{l}\text { Nama } \\
\text { Penulis }\end{array}$ & Tahun & Judul & $\begin{array}{c}\text { Sumber } \\
\text { Artikel }\end{array}$ & $\begin{array}{c}\text { Bidang } \\
\text { Kajian }\end{array}$ & $A B C D$ & Hasil \\
\hline \multicolumn{8}{|c|}{ Jurnal Nasional Terakreditasi } \\
\hline 4. & $\begin{array}{l}\text { Suci } \\
\text { Muliana, } \\
\text { Nurhayani, } \\
\text { H. } \\
\text { Muhiddin } \\
\text { Siti Rahma } \\
\text { Yunus }\end{array}$ & 2019 & $\begin{array}{lr}\text { Pengaruh } & \text { Model } \\
\text { Kooperatif } & \text { Tipe } \\
\text { Group Investigation } \\
\text { Terhadap } \\
\text { Keterampilan } \\
\text { Berpikir } & \text { Kritis } \\
\text { Peserta Didik Pada } \\
\text { Materi r Pokok } \\
\text { Sistem Ekskresi } \\
\text { Kelas VIII SMP } \\
\text { Negeri } & 15 \text { Makasar }\end{array}$ & $\begin{array}{l}\text { Jurnal IPA } \\
\text { Terpadu }\end{array}$ & $\begin{array}{c}\text { Berpikir } \\
\text { Kritis }\end{array}$ & $\sqrt{ } \sqrt{ } \sqrt{ } \sqrt{ }$ & $\sqrt{ }$ \\
\hline 5. & Sutarjo & 2016 & $\begin{array}{l}\text { Pengaruh Strrategi } \\
\text { Pembelajaran } \\
\text { Kooperatif Group } \\
\text { Investigation } \\
\text { Terhadap } \\
\text { Keterampulan } \\
\text { Berpikir Kritis Siswa } \\
\text { Kelas X MIPA MAN } \\
\text { Model Sorong }\end{array}$ & $\begin{array}{c}\text { Jurnal } \\
\text { Biolearning }\end{array}$ & $\begin{array}{c}\text { Berpikir } \\
\text { Kritis }\end{array}$ & $\sqrt{ } \sqrt{ } \sqrt{ }$ & $\sqrt{ }$ \\
\hline 6. & $\begin{array}{l}\text { Meti } \\
\text { Herlina, Isti } \\
\text { Yesti } \\
\text { Rahayu, } \\
\text { Diningsih } \\
\text { Wiksya }\end{array}$ & 2019 & $\begin{array}{l}\text { Pengaruh Model } \\
\text { Pembelajaran } \\
\text { Group Investigation } \\
\text { (GI) Terhadap } \\
\text { Berpikir Kritis Dan } \\
\text { Keterampilan Sosial } \\
\text { Siswa dalam } \\
\text { Pembelajaran IPA } \\
\text { Biologi Kelas X } \\
\text { SMAN } \\
\text { Argamakmur }\end{array}$ & $\begin{array}{l}\text { Diklabio: } \\
\text { Jurnal } \\
\text { pendidikan } \\
\text { dan } \\
\text { pembelaja- } \\
\text { ran biologi }\end{array}$ & $\begin{array}{c}\text { Berpikir } \\
\text { Kritis }\end{array}$ & $\sqrt{ } \quad \sqrt{ } \quad \sqrt{ }$ & $\sqrt{ }$ \\
\hline 7. & $\begin{array}{l}\text { Putri } \\
\text { Wulan, } \\
\text { Hasruddin, } \\
\text { Tumiur } \\
\text { Gultom }\end{array}$ & 2017 & $\begin{array}{l}\text { Pengaruh Model } \\
\text { Pembelajaran } \\
\text { Berbasis Masalah } \\
\text { Dan Investigasi } \\
\text { Kelompok } \\
\text { Terhadap } \\
\text { Kemampuan } \\
\text { Berpikir Kritis Materi } \\
\text { Keanekaragaman } \\
\text { Hayati Siswa SA } \\
\text { Budisatrya Medan }\end{array}$ & $\begin{array}{c}\text { Jurnal } \\
\text { Tabularasa }\end{array}$ & $\begin{array}{c}\text { Berpikir } \\
\text { Kritis }\end{array}$ & $\sqrt{ } \sqrt{ } \sqrt{ } \sqrt{ }$ & $\sqrt{ }$ \\
\hline
\end{tabular}


Bioeduca: Journal of Biology Education

Vol. 3, No. 1 (2021), Hal. $20-36$

\begin{tabular}{|c|c|c|c|c|c|c|c|}
\hline No. & $\begin{array}{c}\text { Nama } \\
\text { Penulis }\end{array}$ & Tahun & Judul & $\begin{array}{c}\text { Sumber } \\
\text { Artikel }\end{array}$ & $\begin{array}{l}\text { Bidang } \\
\text { Kajian }\end{array}$ & $A B C D$ & Hasil \\
\hline 8. & $\begin{array}{l}\text { Septa } \\
\text { Trismanita, } \\
\text { Tri Jalmo } \\
\text { Rini } \\
\text { Rita T } \\
\text { Mapaung }\end{array}$ & 2014 & $\begin{array}{l}\text { Pengaruh } \\
\text { Penerapan Model } \\
\text { Pembelajaran } \\
\text { Group Investigation } \\
\text { Terhadap Aktivitas } \\
\text { Dan Hasil Belajar }\end{array}$ & $\begin{array}{c}\text { Jurnal } \\
\text { Bioterdidik }\end{array}$ & $\begin{array}{l}\text { Aktivitias } \\
\text { lisan }\end{array}$ & $\sqrt{ } \sqrt{ } \quad \sqrt{ } \sqrt{ }$ & $\sqrt{ }$ \\
\hline 9. & $\begin{array}{l}\text { ofi } \\
\text { oktaviani, } \\
\text { Tri Jalmo, } \\
\text { Rini Rita T. } \\
\text { Marpaung }\end{array}$ & 2014 & $\begin{array}{l}\text { Pengaruh } \\
\text { Pembelajaran } \\
\text { Kooperatif Tipe } \\
\text { Group Investigation } \\
\text { (GI) Terhadap } \\
\text { Kemampuan } \\
\text { Berpikir Kritis }\end{array}$ & $\begin{array}{l}\text { Jurnal } \\
\text { Bioterdidik }\end{array}$ & $\begin{array}{l}\text { Berpikir } \\
\text { Kritis }\end{array}$ & $\begin{array}{llll} & \sqrt{ } & \sqrt{ } & \sqrt{ }\end{array}$ & $\sqrt{ }$ \\
\hline 10. & $\begin{array}{l}\text { Indra } \\
\text { Sahfriana, } \\
\text { Wachju } \\
\text { Subchan }\end{array}$ & 2015 & $\begin{array}{l}\text { Penerapan Model } \\
\text { Pembelajaran } \\
\text { Group Investigation } \\
\text { (Gl) }\end{array}$ & $\begin{array}{c}\text { Jurnal } \\
\text { pancaran } \\
\text { pendidikan }\end{array}$ & $\begin{array}{c}\text { Berpikir } \\
\text { Kritis }\end{array}$ & & \\
\hline & Suratno & & $\begin{array}{l}\text { Meningkatkan } \\
\text { Keterampilan Sosial } \\
\text { Siswa Dalam } \\
\text { Pembelajaran IPA } \\
\text { Biologi }\end{array}$ & & & $\sqrt{ } \sqrt{ } \sqrt{ } \sqrt{ }$ & $\sqrt{ }$ \\
\hline 11. & $\begin{array}{l}\text { Talenta } \\
\text { Nauli }\end{array}$ & 2013 & Pengaruh & $\begin{array}{l}\text { Jurnal } \\
\text { Bioterdidik }\end{array}$ & $\begin{array}{l}\text { Aktivitias } \\
\text { lisan }\end{array}$ & & \\
\hline & Harianja & & $\begin{array}{l}\text { Group Investigation } \\
\text { Terhadap Aktivitas } \\
\text { Dan Hasil Belajar } \\
\text { Siswa }\end{array}$ & & & $\sqrt{ } \sqrt{ } \sqrt{ } \sqrt{ }$ & $\sqrt{ }$ \\
\hline 12. & $\begin{array}{l}\text { Firdaus } \\
\text { Daud, } \\
\text { Nunu Dwi } \\
\text { Warti }\end{array}$ & 2011 & $\begin{array}{l}\text { Pengaruh } \\
\text { Penerapan Model } \\
\text { Pembelajaran } \\
\text { Kooperatif Tipe } \\
\text { Group Investigation }\end{array}$ & $\begin{array}{l}\text { Jurnal } \\
\text { Bionature }\end{array}$ & $\begin{array}{l}\text { Aktivitias } \\
\text { lisan }\end{array}$ & & \\
\hline & & & $\begin{array}{l}\text { Terhadap Aktivitas } \\
\text { Dan Hasil Belajar } \\
\text { Siswa Kelas X SMA }\end{array}$ & & & $\begin{array}{llll}\sqrt{ } & \sqrt{ } & \sqrt{ }\end{array}$ & $\sqrt{ }$ \\
\hline & & & $\begin{array}{lll}\text { Negeri } & 1 & \text { Bajeng } \\
\text { Pada } & & \text { Konsep } \\
\text { Ekosistem } & \end{array}$ & & & & \\
\hline 13. & $\begin{array}{l}\text { Natalia } \\
\text { Desiana } \\
\text { Naikteas }\end{array}$ & 2019 & $\begin{array}{lr}\text { Penerapan } & \text { Model } \\
\text { Numbered } & \text { Head } \\
\text { Together } & \text { Dan }\end{array}$ & $\begin{array}{l}\text { Edufisika : } \\
\text { jurnal } \\
\text { pendidikan }\end{array}$ & $\begin{array}{l}\text { Berpikir } \\
\text { Kritis }\end{array}$ & & \\
\hline & $\begin{array}{l}\text { Bano, } \\
\text { Amiruddin } \\
\text { supu, } \\
\text { vinsnsius } \\
\text { lantik }\end{array}$ & & $\begin{array}{l}\text { Group Investigation } \\
\text { Untuk } \\
\text { Meningkatkan } \\
\text { Kemampuan } \\
\text { Bepikir Kritis Siswa }\end{array}$ & fisika & & $\sqrt{ } \sqrt{ } \sqrt{ } \sqrt{ }$ & $\sqrt{ }$ \\
\hline 14. & $\begin{array}{l}\text { Ana } \\
\text { Yuniasti, } \\
\text { Retno } \\
\text { Wulandari }\end{array}$ & 2014 & $\begin{array}{l}\text { Pengaruh } \\
\text { Pembelajaran } \\
\text { Kooperatif Tipe } \\
\text { Student Team } \\
\text { Achievement } \\
\text { Division (STAD) } \\
\text { Dan Group } \\
\text { Investigation (GI) } \\
\text { Ditinjau Dari } \\
\text { Aktivitas Belajar }\end{array}$ & $\begin{array}{l}\text { Jurnal Pena } \\
\text { Sains }\end{array}$ & $\begin{array}{l}\text { Aktivitias } \\
\text { lisan }\end{array}$ & $\sqrt{ } \sqrt{ } \sqrt{ } \sqrt{ }$ & $\sqrt{ }$ \\
\hline
\end{tabular}


Bioeduca: Journal of Biology Education

Vol. 3, No. 1 (2021), Hal. $20-36$

\begin{tabular}{|c|c|c|c|c|c|c|c|}
\hline No. & $\begin{array}{c}\text { Nama } \\
\text { Penulis }\end{array}$ & Tahun & Judul & $\begin{array}{c}\text { Sumber } \\
\text { Artikel }\end{array}$ & $\begin{array}{l}\text { Bidang } \\
\text { Kajian }\end{array}$ & $A B C D$ & Hasil \\
\hline 15. & $\begin{array}{l}\text { Bunga } \\
\text { Mahardika } \\
\text { Asokawati, } \\
\text { Antonius } \\
\text { Tri Widodo, } \\
\text { Sri } \\
\text { Mursiti }\end{array}$ & 2018 & $\begin{array}{lr}\text { Pengaruh } & \text { Model } \\
\text { Pembelajaran } & \\
\text { Kooperatif } & \\
\text { Terintegrasi } & \\
\text { Investigasi } & \\
\text { Terhadap } & \text { Hasil } \\
\text { Belajar } & \text { dan } \\
\text { Aktivitas } & \text { Siswa } \\
\text { SMA } & \end{array}$ & $\begin{array}{l}\text { Jurnal } \\
\text { Inovasi } \\
\text { Pendidikan } \\
\text { kimia }\end{array}$ & $\begin{array}{c}\text { Aktivitias } \\
\text { lisan }\end{array}$ & $\sqrt{ } \quad \sqrt{ } \quad \sqrt{ } \quad \sqrt{ }$ & $\sqrt{ }$ \\
\hline 16. & $\begin{array}{l}\text { Vera } \\
\text { Pangni } \\
\text { Fahriani, } \\
\text { Wawan } \\
\text { Wahyu, } \\
\text { Nuhadi, } \\
\text { Reza } \\
\text { Setiawan } \\
\text { Rahmat } \\
\text { Hidayat }\end{array}$ & 2019 & $\begin{array}{l}\text { Pengaruh Model } \\
\text { Pembelajaran } \\
\text { Kooperatif Tipe } \\
\text { Group Investigation } \\
\text { (MPKTGI) } \\
\text { Terhadap } \\
\text { Kemampuan } \\
\text { Berkomunikasi } \\
\text { Pada Topik Titrasi } \\
\text { Asam Basa }\end{array}$ & $\begin{array}{c}\text { Jurnal } \\
\text { Dinamika } \\
\text { Pendidikan }\end{array}$ & $\begin{array}{c}\text { Aktivitias } \\
\text { lisan }\end{array}$ & $\sqrt{ } \sqrt{ } \quad \sqrt{ } \sqrt{ }$ & $\sqrt{ }$ \\
\hline 17. & $\begin{array}{l}\text { Baiq } \\
\text { Ismayawati, } \\
\text { Agus Abhi } \\
\text { Purwoko, } \\
\text { Muntari }\end{array}$ & 2016 & $\begin{array}{l}\text { Pengaruh Model } \\
\text { Pembelajaran } \\
\text { Berbasis Masalah } \\
\text { (PBM) Dalam } \\
\text { Setingan } \\
\text { Pembelajaran } \\
\text { Kooperatig Tipe } \\
\text { TGT Dan GI } \\
\text { Terhadap } \\
\text { Keterampilan } \\
\text { Berpikir Kritis Dan } \\
\text { Hasil Belajar Kimia } \\
\text { Pesera Didik SMAN } \\
\text { 1 Aikmel }\end{array}$ & $\begin{array}{l}\text { Jurnal } \\
\text { Penelitian } \\
\text { Pendidikan } \\
\text { IPA }\end{array}$ & $\begin{array}{l}\text { Berpikir } \\
\text { Kritis }\end{array}$ & $\sqrt{ } \sqrt{ } \sqrt{ } \sqrt{ }$ & $\sqrt{ }$ \\
\hline 18. & $\begin{array}{l}\text { Putri D A P } \\
\text { Rai } \\
\text { Sujanem } \\
\text { Putu Yasa }\end{array}$ & 2019 & $\begin{array}{l}\text { Pengaruh Model } \\
\text { Pembelajaran } \\
\text { Kooperatif Tipe } \\
\text { Group Investigation } \\
\text { Berbantuan Mind } \\
\text { Map Terhadap } \\
\text { Keterampilan } \\
\text { Berpikir Kritis Siswa } \\
\text { Dalam } \\
\text { Pembelajaran } \\
\text { Fisika }\end{array}$ & $\begin{array}{l}\text { Jurnal } \\
\text { Pendidikan } \\
\text { Fisika } \\
\text { Undiskha }\end{array}$ & $\begin{array}{c}\text { Berpikir } \\
\text { Kritis }\end{array}$ & $\sqrt{ } \sqrt{ } \sqrt{ }$ & $\sqrt{ }$ \\
\hline 19. & $\begin{array}{l}\text { Nadiya } \\
\text { Haris } \\
\text { Rosdianto } \\
\text { Eka } \\
\text { Murdani }\end{array}$ & 2016 & $\begin{array}{l}\text { Penerapan model } \\
\text { pembelajaran group } \\
\text { investigation (Gl) } \\
\text { untuk } \\
\text { meningkatkan } \\
\text { keterampilan } \\
\text { berpikir kritis siswa } \\
\text { pada materi gerak } \\
\text { lurus kelas X }\end{array}$ & $\begin{array}{l}\text { Jurnal Ilmu } \\
\text { Pendidikan } \\
\text { Fisika }\end{array}$ & $\begin{array}{l}\text { Berpikir } \\
\text { Kritis }\end{array}$ & $\sqrt{ } \sqrt{ } \sqrt{ } \sqrt{ }$ & $\sqrt{ }$ \\
\hline 20. & $\begin{array}{l}\text { Ni Km. } \\
\text { Inten } \\
\text { Phramesti }\end{array}$ & 2018 & $\begin{array}{l}\text { Pengaruh model } \\
\text { pembelajaran group } \\
\text { investigation } \\
\text { berbantuan media } \\
\text { questions card }\end{array}$ & $\begin{array}{c}\text { Thinking Skill } \\
\text { and } \\
\text { Creativity } \\
\text { Jurnal }\end{array}$ & $\begin{array}{l}\text { Berpikir } \\
\text { Kritis } \\
\& \\
\text { Materi } \\
\text { Biologi }\end{array}$ & $\sqrt{ } \sqrt{ } \quad \sqrt{ } \sqrt{ }$ & $\sqrt{ }$ \\
\hline
\end{tabular}


Bioeduca: Journal of Biology Education

Vol. 3, No. 1 (2021), Hal. $20-36$

\begin{tabular}{|c|c|c|c|c|c|c|c|}
\hline No. & $\begin{array}{c}\text { Nama } \\
\text { Penulis }\end{array}$ & Tahun & Judul & $\begin{array}{l}\text { Sumber } \\
\text { Artikel }\end{array}$ & $\begin{array}{l}\text { Bidang } \\
\text { Kajian }\end{array}$ & A B C D & Hasil \\
\hline 21. & $\begin{array}{l}\text { Putri Nym } \\
\text { Murda } \\
\text { Dewa } \\
\text { Nym } \\
\text { Sudana } \\
\text { Zahratul } \\
\text { Aini, Agus } \\
\text { Ramdani, } \\
\text { Ahmad } \\
\text { Raksun }\end{array}$ & 2018 & $\begin{array}{l}\text { terhadap } \\
\text { pemahaman } \\
\text { konsep dan } \\
\text { keterampilan } \\
\text { berpikir kritis IPA } \\
\text { Perbedaan } \\
\text { Penguasaan } \\
\text { Konsep Biologi dan } \\
\text { Kemampuan } \\
\text { berpikir kritis siswa } \\
\text { kelas X pada } \\
\text { Penerapan model } \\
\text { pembelajaran } \\
\text { kooperatif Tipe } \\
\text { group investigation } \\
\text { dan guided inquiry } \\
\text { di MAN 1 Praya }\end{array}$ & $\begin{array}{l}\text { Jurnal pijar } \\
\text { MIPA }\end{array}$ & $\begin{array}{l}\text { Materi } \\
\text { Biologi }\end{array}$ & $\sqrt{ } \sqrt{ } \quad \sqrt{ } \sqrt{ }$ & $\sqrt{ }$ \\
\hline \multicolumn{8}{|c|}{ Jurnal Nasional Terakreditasi } \\
\hline 22. & $\begin{array}{l}\text { Elvi Marini, } \\
\text { Parham } \\
\text { Saadi }\end{array}$ & 2017 & $\begin{array}{l}\text { Pengaruh Model } \\
\text { Pembelajaran } \\
\text { Group } \\
\text { Investigation (GI) } \\
\text { Berbantuan Lembar } \\
\text { Kerja Peserta Didik } \\
\text { Terhadap } \\
\text { Kemampuan } \\
\text { Berpikir Kritis dan } \\
\text { Hasil Belajar Siswa } \\
\text { Kelas X SMA } \\
\text { Negeri } \quad 10 \\
\text { Banjarmasin Pada } \\
\text { Materi Hidrokarbon }\end{array}$ & $\begin{array}{l}\text { Journal Of } \\
\text { Chemistry } \\
\text { And } \\
\text { Education }\end{array}$ & $\begin{array}{l}\text { Berpikir } \\
\text { Kritis }\end{array}$ & $\sqrt{ } \sqrt{ } \quad \sqrt{ }$ & $\sqrt{ }$ \\
\hline 23. & $\begin{array}{l}\text { Binti } \\
\text { Hifdhotun } \\
\text { Al Aslahah, } \\
\text { Herawati } \\
\text { Susilo, } \\
\text { Triastono } \\
\text { Iman } \\
\text { Prasetyo }\end{array}$ & 2014 & $\begin{array}{l}\text { Pengaruh Strategi } \\
\text { Pembelajaran } \\
\text { Group Investigation } \\
\text { (Gl) Terhadap } \\
\text { Kemampuan } \\
\text { Berpikir Kritis Siswa } \\
\text { Sma Di Kota } \\
\text { Malang }\end{array}$ & $\begin{array}{c}\text { Jurnal Online } \\
\text { UM }\end{array}$ & $\begin{array}{l}\text { Berpikir } \\
\text { Kritis }\end{array}$ & $\sqrt{ } \sqrt{ } \sqrt{ } \sqrt{ }$ & $\sqrt{ }$ \\
\hline 24. & $\begin{array}{l}\text { Winda } \\
\text { Miraningsih } \\
\text { Utiya Aziza }\end{array}$ & 2015 & $\begin{array}{l}\text { Penerapan model } \\
\text { pembelajaran } \\
\text { kooperatif Tipe } \\
\text { group investigation } \\
\text { untuk melatih } \\
\text { keterampilan } \\
\text { berpikir kritis siswa } \\
\text { pada materi pokok } \\
\text { asam basa kelas XI } \\
\text { MIA SMAN } 2 \\
\text { Magetan }\end{array}$ & $\begin{array}{l}\text { Jurnal Of } \\
\text { Chemical } \\
\text { Education }\end{array}$ & $\begin{array}{l}\text { Berpikir } \\
\text { Kritis }\end{array}$ & $\sqrt{ } \sqrt{ } \quad \sqrt{ }$ & $\sqrt{ }$ \\
\hline 25. & $\begin{array}{l}\text { Widianingsi } \\
\mathrm{h}, \mathrm{H} . \text {, } \\
\text { Suganda, } \\
\text { O., \& } \\
\text { Widiantie, } \\
\text { R. }\end{array}$ & 2015 & $\begin{array}{l}\text { Penggunaan Model } \\
\text { Group Investigation } \\
\text { (GI) Dengan } \\
\text { Macromedia Flash } \\
\text { Player Untuk } \\
\text { Meningkatkan }\end{array}$ & $\begin{array}{c}\text { Quagga: } \\
\text { Jurnal } \\
\text { Pendidikan } \\
\text { Dan Biologi }\end{array}$ & $\begin{array}{l}\text { Materi } \\
\text { Biologi }\end{array}$ & $\sqrt{ } \sqrt{ } \sqrt{ } \sqrt{ }$ & $\sqrt{ }$ \\
\hline
\end{tabular}


Bioeduca: Journal of Biology Education

Vol. 3, No. 1 (2021), Hal. $20-36$

\begin{tabular}{|c|c|c|c|c|c|c|c|}
\hline No. & $\begin{array}{c}\text { Nama } \\
\text { Penulis }\end{array}$ & Tahun & Judul & $\begin{array}{l}\text { Sumber } \\
\text { Artikel }\end{array}$ & $\begin{array}{l}\text { Bidang } \\
\text { Kajian }\end{array}$ & A B C D & Hasil \\
\hline & & & \begin{tabular}{lr}
\multicolumn{2}{l}{ Penguasaan } \\
Konsep & Sistem \\
Pernapasan & Pada \\
Manusia & Siswa \\
Kelas VII SMP & SMeri 4 Kuningan
\end{tabular} & & & & \\
\hline \multicolumn{8}{|c|}{ Prosiding } \\
\hline 26. & $\begin{array}{l}\text { Dakhoria } \\
\text { Maula, } \\
\text { Tabitha Sru } \\
\text { Hartati } \\
\text { Wulandari }\end{array}$ & 2018 & $\begin{array}{l}\text { Pengaruh Model } \\
\text { Pembelajaran } \\
\text { Kooperatif Tipe } \\
\text { Group Investigation } \\
\text { (Gl) Dengan Media } \\
\text { Flash Card } \\
\text { Terhadap } \\
\text { Kemampuan } \\
\text { Berpikir Kritis Siswa } \\
\text { SMP }\end{array}$ & $\begin{array}{l}\text { Proceeding } \\
\text { Biology } \\
\text { Education } \\
\text { Conference }\end{array}$ & $\begin{array}{c}\text { Berpikir } \\
\text { Kritis }\end{array}$ & $\sqrt{ } \sqrt{ } \quad \sqrt{ } \sqrt{ }$ & $\sqrt{ }$ \\
\hline 27. & $\begin{array}{l}\text { Putu Prima } \\
\text { Juniartina }\end{array}$ & 2015 & $\begin{array}{lr}\text { Pengaruh } & \text { Model } \\
\text { Pembelajaran } & \\
\text { Kooperatif Group } \\
\text { Investigation } & \\
\text { Terhadap } & \\
\text { Pemahaman } & \\
\text { Konsep } & \text { Dan } \\
\text { Kemampuan } & \\
\text { Berpikir Kritis Siswa } \\
\text { Kelas Xi la } \\
\text { SMA Negeri } 4 \\
\text { Singaraja } & \end{array}$ & $\begin{array}{l}\text { Proceedings } \\
\text { Seminar } \\
\text { Nasional } \\
\text { FMIPA }\end{array}$ & $\begin{array}{l}\text { Berpikir } \\
\text { Kritis }\end{array}$ & $\sqrt{ } \sqrt{ } \sqrt{ }$ & $\sqrt{ }$ \\
\hline \multirow[t]{4}{*}{28.} & $\begin{array}{l}\text { Sophya } \\
\text { Latansya } \\
\text { Amaliah, }\end{array}$ & 2019 & $\begin{array}{l}\text { Pengaruh Model } \\
\text { Pembelajaran } \\
\text { Reading Concept } \\
\text { Mapping Group }\end{array}$ & $\begin{array}{l}\text { Seminar } \\
\text { Nasional } \\
\text { Biologi, } \\
\text { Saintek, dan }\end{array}$ & $\begin{array}{c}\text { Berpikir } \\
\text { Kritis }\end{array}$ & & \\
\hline & $\begin{array}{l}\text { Purwanti } \\
\text { Kuswarni } \\
\text { Suprapto, }\end{array}$ & & $\begin{array}{l}\text { Investigation } \\
\text { (RemapGI) } \\
\text { Terhadap } \\
\text { Kemampuan }\end{array}$ & $\begin{array}{c}\text { Pembelajara } \\
\text { nnya (SN- } \\
\text { Biosper) }\end{array}$ & & $\sqrt{ } \sqrt{ } \quad \sqrt{ } \quad \sqrt{ }$ & $\sqrt{ }$ \\
\hline & Rita Fitriani & & $\begin{array}{ll}\text { Berpikir } & \text { Kritis } \\
\text { Peserta Didik }\end{array}$ & & & & \\
\hline & & & $\begin{array}{l}\text { Pada Sub Konsep } \\
\text { Sistem Endokrin }\end{array}$ & & & & \\
\hline 29. & $\begin{array}{l}\text { Siti Nina } \\
\text { Ilmayuni, } \\
\text { Edi } \\
\text { Hernawan, } \\
\text { Liah } \\
\text { Badriah }\end{array}$ & 2019 & $\begin{array}{lr}\text { Penerapan } & \text { Model } \\
\text { Group Investigation } \\
\text { Dengan } \\
\text { Pendekatan } \\
\text { Problem } \\
\text { Learning } \quad \text { Posing } \\
\text { Terhadap } & \\
\text { Kemampuan } & \\
\text { Berpikir Kritis } & \end{array}$ & $\begin{array}{c}\text { Seminar } \\
\text { Nasional } \\
\text { Biologi, } \\
\text { Saintek, dan } \\
\text { Pembelajara } \\
\text { nnya (SN- } \\
\text { Biosper) }\end{array}$ & $\begin{array}{c}\text { Berpikir } \\
\text { Kritis }\end{array}$ & $\sqrt{ } \sqrt{ } \quad \sqrt{ } \sqrt{ }$ & $\sqrt{ }$ \\
\hline \multicolumn{8}{|c|}{ Repository Skripsi / Thesis } \\
\hline 30. & $\begin{array}{l}\text { Ahmad } \\
\text { Fauzi }\end{array}$ & 2019 & $\begin{array}{l}\text { Pengaruh model } \\
\text { pembelajaran } \\
\text { inkuiri dang group } \\
\text { investigation } \\
\text { terhadap }\end{array}$ & Thesis & $\begin{array}{c}\text { Berpikir } \\
\text { Kritis }\end{array}$ & $\sqrt{ } \sqrt{ } \quad \sqrt{ } \sqrt{ }$ & $\sqrt{ }$ \\
\hline
\end{tabular}


Bioeduca: Journal of Biology Education

Vol. 3, No. 1 (2021), Hal. $20-36$

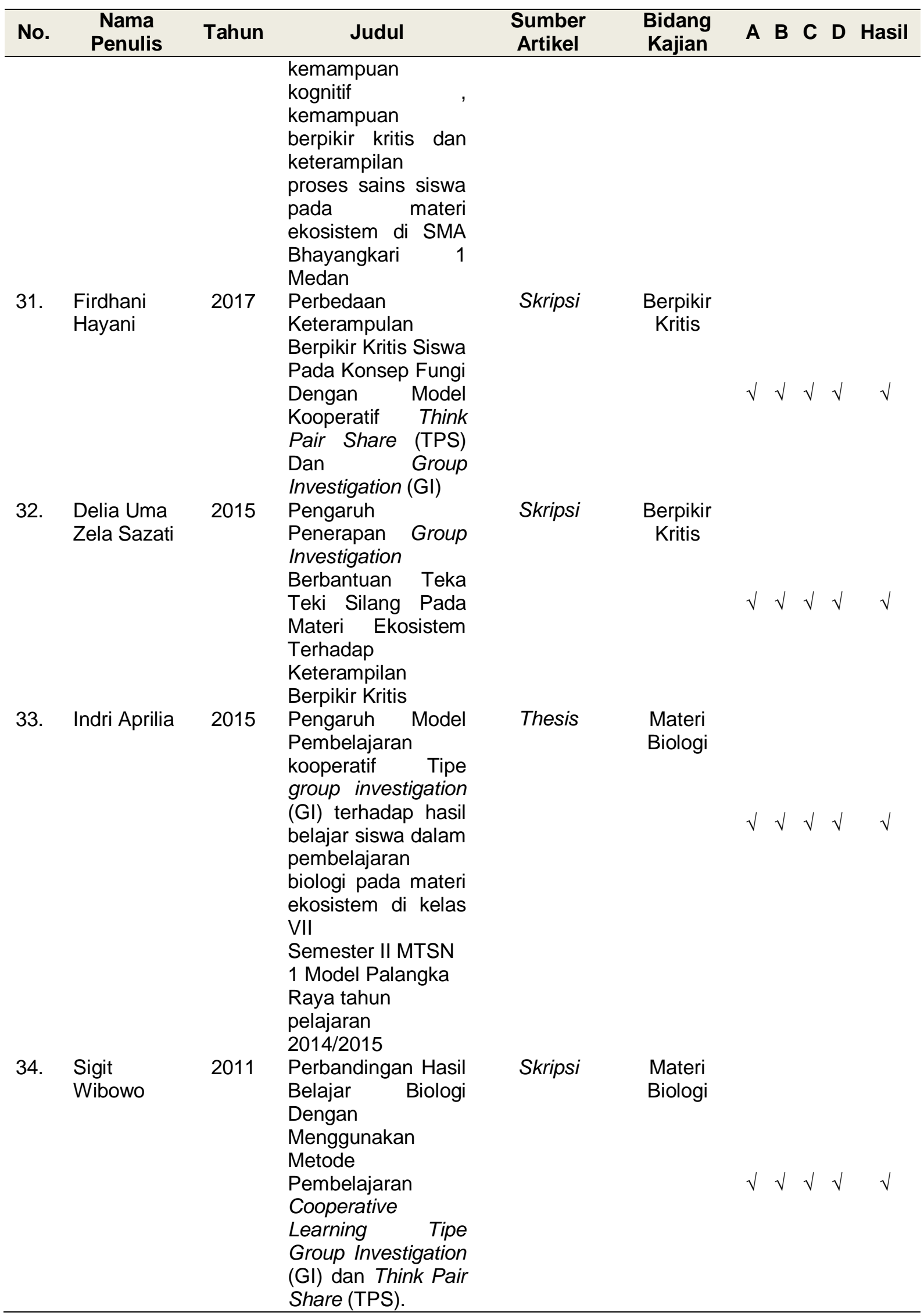




\section{HASIL PENELITIAN DAN PEMBAHASAN}

Berdasarkan hasil validasi artikel dikelompokan jurnal yang termasuk kedalam pengaruh group investigation terhadap berpikir kritis, aktivitas lisan dan materi biologi.

Tabel 2. Pengelompokan jurnal berdasarkan bidang kajian artikel

\begin{tabular}{llc}
\hline No & \multicolumn{1}{c}{ Bidang Kajian } & Jumlah \\
\hline 1. & Pengaruh model Gl Terhadap Berpikir Kritis & 23 \\
2. & Pengaruh model Gl Terhadap Aktivitas lisan & 6 \\
3. & Pengaruh model Gl Terhadap Materi Biologi & 5 \\
\hline
\end{tabular}

Pembahasan pada artikel ini memiliki 4 poin diantaranya sebagai berikut :

1. Pengaruh Model Group Investigation (Gl) Terhadap Kemampuan Berpikir Kritis

Kesenjangan dari beberapa literatur menyebutkan bahwa berpikir kritis perlu dibekali bagi siswa terutama dalam bidang teknologi dan era globalisasi saat ini. Kemampuan berpikir kritis berguna bagi siswa mengambil sebuah keputusan mengenai sebuah informasi secara tepat dan benar. Kurikulum 2013 yang dibuat berfokus juga pada peningkatan kemampuan berpikir kritis siswa. Salah satu pembelajaran yaitu IPA terkhusus pada mata pelajaran biologi menyatakan sesuai dengan kurikulum 2013 dalam proses pembelajaran yang meningkatkan kemampuan berpikir kritis. Proses pembelajaran sudah dirancang dari guru secara efektif dan efesien namun secara pelaksanaan proses pembelajaran belum bisa diterapkan sesuai dengan RPP yang telah dirancang. Hal tersebut membuat berpikir kritis siswa belum optimal dikembangkan. Proses pembelajaran yang dilakukan guru cenderung pada penyampaian informasi saja dan menghal, hal tersebut membuat siswa menjadi bosan.

Penggunaan model pembelajaran yang kurang efektif memerlukan model lain, salah satunya model group investigation (Gl). Menurut Santyasa et al., (2019) berpendapat bahwa langkah investigasi pada model pembelajaran group investigation (Gl) mampu membuat siswa melakukan penyelidikan mengenai suatu topik yang kontekstual, sehingga siswa menemukan sebuah solusi alternatif. Langkah investigasi pada model group investigation (GI) mampu membuat siswa mengoptimalkan potensi dalam kelompoknya sehingga siswa mampu mengembangkan ide kreatif dan kritis, berwawasan dan keingan untuk berbagi pengalaman (Aini et al., 2018). Tahap lainya yaitu tahap presentasi berpengaruh terhadap kemampuan berpikir kritis. Hal tersebut diketahui dari kemampuan siswa yang presentasi dalam menanggapi pertanyaan terhadap pertanyaan dari siswa yang bertanya (Rosiani et al., 2020).

Pembelajaran group investigation (Gl) yang membuat siswa aktif dalam pembelajaran sehingga siswa mampu menemukan konsep pembelajaran secara mandiri dan mampu memecahkan permasalahan yang ada kaitan dengan konsep pembelajaran lain (Anggis, 2018). Model group investigation (Gl) menekankan siswa untuk melakukan penyelidikan dan pemecahan masalah terutama maslahmasalah lingkungan yang ada disekitar untuk memberdayakan keterampilan berpikir siswa (Aini et al., 2018). Nilai posttest dari beberapa literatur menyebutkan 
bahwa kemampuan berpikir kritis siswa dalam katagori rendah, sedang, dan tinggi. Jawaban dari posttest siswa sudah mendukung dalam indikator berpikir kritis.

Menurut Hayani (2017) katagori tinggi terdapat pada indikator mengatur strategi dan taktik. Indikator lain yang termuat diantaranya melakukan deduksi, melakukan induksi dan melakukan evaluasi dan memberikan argumen. Siswa dapat memahami pengetahuan baru dengan cara menganalisis dan mensintesis sehingga menemukan sebuah pemahaman pemahaman ini menjadi landasan berpikir kritis (Oktaviani et al., 2014). Menurut Nadiya et al., (2016) indikator yang sudah memuat bepikir kritis diantarnaya menyimpulkan, penyelidikan, menganalisis pemecahan masalah dan membuat kesimpulan. Terdapat 5 indikator yaitu ekplanasi, analisis, evaluasi, interprestasi dan memberikan kesimpulan namun masih dalam katagori rendah (Bano et al., 2019). Menurut Maula et al., (2018) indikator yang termuat dalam jawaban posttes sisswa ialah menganalisis argumen, pertanyaan yang membutuhkan suatu penjelasan midentifikasi istilah, mempertimbangkan suatu definisi dan memfokuskan suatu tindakan. Indikator yang diamuat diantaranya memberikan penjelasan sederhana, membangun keterampilan dasar dan menyimpulkan, membuat penjelasan sederhana, strategi dan taktik, indikator strategi dan taktik dengan katagori tinggi pada model group investigation (Gl) (Hayani, 2017).

Terdapat beberapa faktor yang mempengaruhi kemampuan berpikir kritis dalam model pembelajaran group investigation (Gl) diantaranya Menurut Santyasa et al., (2019) faktor yang menyebabkan kurang optimalnya model pembelajaran group investigation (Gl) dalam berpikir kritis yaitu kurang terbiasanya siswa dalam pembelajaran. Kurang optimal model group investigation (Gl) disebabkan dari kurang konsistenya pembelajaran yang dilakukan oleh guru. Kemudian kendala lain bisa diketahui dari model group investigation (GI) yang sulit diterapkan oleh siswa (Aslahah et al.,2016). Hasil dari studi literatur yang menyebutkan bahwa kemampuan berpikir kritis siswa memiliki pengaruh terhadap model pembelajaran group investigation.

\section{Pengaruh Model Group Investigation (Gl) Terhadap Aktivias lisan}

Kesenjangan dari beberapa literatur menyebutkan bahwa pendidikan diarahkan mampu mengembangkan peradaban manusia, hal tersebut dilakukan melalui belajar mengajar. Keberhasilan belajar dipengaruhi dari adanya dari interaksi siswa. Biologi berkaitan dengan pengetahuan tentang alam secara sistematis. Pengetahuannya di dapatkan salah satunya melalui bertanya. Selain itu komunikasi juga perlu dalam proses pembelajaran. Komunikasi mampu menciptakan pembelajaran menjadi optimal. Proses pembelajaran efektif salah satunya melalui model group investigation (GI) yang mampu membuat siswa berdiskusi bersama kelompok, sehingga membuat aktivitas lisan siswa terlihat. Model group investigation (Gl) ialah model yang mampu melatih siswa untuk bertanya, hal tersebut dikarenakan dari model group investigation (Gl) 
memberikan siswa untuk melakukan bertanya, namun guru perlu memberikan motivasi dan minat siswa dalam belajar (Riani et al., 2017).

Kelebihan pembelajaran group investigation (GI) menurut Yuniasti \& Wulandari (2014) yaitu aktivitas siswa dalam pembelajaran ialah sering bertanya, menjawab pertanyaan dan sering berpendapat. Adanya aktivitas tersebut, siswa dapat mengkontruksikan pengetahuannya, kemudian siswa dapat bekerjasama dalam belajar dalam kelompoknya. Indikator aktivitas lisan siswa dengan model group investigation (Gl) ialah siswa aktif bertanya dan menyampaikan pendapat (Asokawati et al., 2018). Menurut Daud dan Warti (2011) Model group investigation (Gl) membuat siswa aktif dalam mengajukan pertanyaan dan menjawab pertanyaan serta menyelesaikan permaslahan dengan berdiskusi, hal ini membuat siswa lebih antusias dalam belajar.

Model group investigation (Gl) mampu membuat siswa diberikan kesempatan bertanya saat presentasi. Kemampuan bertanya siswa meningkat, hal ini dikarenakan dari siswa yang memiliki sub topik yang berbeda sehingga rasa tahu siswa terhadap submateri lainya juga tinggi (Trismanita et al., 2014). Menurut Fahriani et al., (2019) tahap mempresentasikan pada model group investigation (Gl) mampu membuat siswa juga aktif dalam bertanya kepada kelompok yang mempresentasikan. Siswa bertanya tidak hanya saat diskusi dan waktu tanya jawab saja, melainkan yang bertanya mampu mersepon dari jawaban yang telah disampaikan, hal ini mampu juga melatih kemampuan berpikir kritis siswa. Hasil dari studi literatur yang menyebutkan bahwa kemampuan berpikir kritis siswa memiliki pengaruh terhadap model pembelajaran group investigation (Gl).

\section{Pengaruh Model Group Investigation (GI) Pada Materi Biologi}

Materi biologi yang diajarkan di sekolah diketahui materi yang sulit bagi siswa dalam memahami konsep. Kemudian banyak istilah-istilah dalam materi biologi yang belum banyak dimengerti oleh siswa. Menurut Damaryanti (2017) materi biologi merupakan materi yang sulit dipahami oleh siswa. Hal tersebut di karenakan materi yang diajarkan banyak menggunakan istilah biologi dan bahasa latin sehingga siswa dituntut untuk memahami bukan hanya menghafal. Ruang lingkup kajian biologi memiliki kaitan yang erat dengan kehidupan manusia beserta lingkungan. Akan tetapi materi biologi banyak dikatakan sebagai materi yang abstrak. Hal tersebut dikarenakan siswa tidak dapat menemukan secara langsung mengetahui materi biologi, sehingga membutuhkan model pembelajaran yang tepat (Murdiyani, 2012).

Materi biologi yang abstrak akan mudah dipahami oleh siswa jika dilakukan dengan pembelajaran yang menyenakan dan pengalaman siswa menemukan informasi secara mandiri. Pembelajaran biologi dengan materi yang abstrak lebih baik dengan pembelajaran yang kontekstual (Insyasiska et al., 2015). Pembelajaran kontekstual merupakan kegiatan pembelajaran yang mengaitkan suatu konsep pembelajaran terhadap suatu materi yang telah diajarkan dan dapat disesuaikan dengan keadaan sebenarnya (nyata), sehingga membuat siswa dapat 
termotivasi untuk memahami suatu pengetahuan dan dapat mengimplementasikan dalam kehidupan sehari-hari (Nilasari et al., 2016). Salah satu model pembelajaran yang berkaitan dengan pembelajaran kontekstual ialah model pembelajaran group investigation (GI). Menurut Santyasa (2019) Model group investigation (Gl) dalam pembelajaran menekankan pada pembelajaran kontekstual. Pengalaman belajar siswa yang kontekstual mampu membuat siswa memahami materi lebih lama bahkan dapat secara permanen memahami materi. Model pembelajaran group investigation (GI) mampu membuat siswa mengintegrasikan suatu hubungan yang berkaitan dengan penguasaan konsep. Hal ini diketahui dari siswa yang melakukan kegiatan menganalisis dan mensitesis informasi dan mampu menyelesaikan masalah (Wibowo, 2011).

Model pembelajaran group investigation (GI) memiliki karakteristik yang memberikan penekanan kepada siswa dalam meningkatkan partisipasi dan mampu memberikan sebuah informasi dari pelajaran yang telah dipelajari. Siswa dilibatkan dalam pembelajaran melalui perencanan dengan baik oleh guru dalam menentukan topik maupun melakukan investigasi, sehingga pembelajaran model group investigation (Gl) dapat membuat siswa mandiri dalam mencari pengetahuan. Menurut Linda (2010) tujuan pembelajaran group investigation (Gl) ini menjadikan siswa berkelompok, sehingga membuat siswa belajar dalam menyelidiki suatu topik yang dilakukan secara sistematis dan analisis (Wibowo, 2011).

Kegiatan berkelompok ini membuat siswa aktif melakukan percobaan dengan memungkinkan siswa untuk menemukan prinsip dari suatu materi. Kegiatan diskusi dalam kelompok pada saat pembelajaran, membuat siswa dapat menyelesaikan atau memecahkan suatu masalah, sehingga siswa dapat menemukan sebuah kesimpulan. Model pembelajaran group investigation (Gl) mampu membuat siswa melakukan pembelajaran secara mendalam terhadap suatu materi, sehingga materi mudah diingat oleh siswa (Wibowo, 2011). Berdasarkan pembahasan tersebut diketahui model group investigation (GI) berpengaruh pada materi biologi.

\section{Kemampuan Berpikir Kritis Pada Materi Biologi}

Materi biologi diketahui memiliki konsep materi pembelajaran yang cenderung abstrak, sehingga pembelajaran harus berkaitan dengan suatu fakta-fakta yang dialami oleh siswa dalam kehidupan sehari-hari (Suryani et al., 2018). Materi biologi yang abstrak perlu dilakukan visualisasi atau memeberikan gambaran untuk memudahkan siswa memahaminya. Sehingga siswa memahami konsep biologi dan tidak terjadi miskonsepsi (Suswina, 2016). Selaras menurut Juwita et al. (2014) karakteristik dari materi biologi merupakan materi yang sulit yang dianggap dari siswa, hal tersebut dikarenakan materinya cenderung abstrak. Materi yang abstrak ini perlu adanya pemikiran secara mendalam agar tidak terjadi miskonsepsi terhadap pengetahuan mengenai materi biologi. Salah satu berpikir secara mendalam mengenai suatu hal ialah dengan berpikir kritis. 
Surya et al. (2014) mengatakan bahwa berpikir kritis terhadap suatu materi memiliki tujuan yaitu agar siswa mampu membuat kesimpulan dengan tepat berdasarkan pemahaman yang telah di konfirmasi ke guru atau ahli terhadap materi tersebut sehingga mendapatkan sebuah pengetahuan yang benar dan tidak miskonsepsi terhadap suatu pengetahuan. Berdasarkan hasil posttest tersebut, terdapat indikator berpikir kritis yang berkaitan dalam materi biologi. Indikator berpikir kritis yang berkaitan dengan materi biologi, diantarnya indikator memberikan penjelasan lanjut, penjelasan sederhana dan menyimpulkan. Indikator memberikan penjelasn lanjut dengan sub indikator yaitu mengidentifikasi asumsi. Kemudian indikator berpikir kritis memberikan penjelasan sederhana pada sub indikator argumentasi. Sub indikator argumentasi ini diketahui dari siswa mampu berargumentasi dan menjelaskan konsep biologi secara logis. Terdapat indikator berpikir kritis selanjutnya ialah menyimpulkan dalam sub indikator deduksi dan induksi. Sub indikator ini membuat siswa mampu menyimpulkan suatu pemahaman mengenai materi biologi Indikator berpikir kritis dalam materi sitem pernapasan membuat siswa menemukan suatu pengetahuan yang benar tanpa ada miskonsepsi, sehingga siswa mendapatkan sebuah pengalaman belajar yang bermakna et al., 2014). Berdasarkan pembahasan tersebut diketahui bahwa kemampuan berpikir kritis terdapat pada materi biologi.

\section{SIMPULAN DAN SARAN}

Langkah pembelajaran group investigation (GI) berpengaruh terhadap berpikir kritis yaitu langkah investigasi dan presentasi, selain itu syntak pembelajaran GI mampu membuat siswa melakukan penyeledikan dan pemecahan masalah. Model pembelajaran GI mampu membuat siswa aktif dalam pembelajaran seperti sering bertanya, menjawab pertanyaan dan sering berpendapat, terutama pada langkah mempresentasikan. Model pembelajaran Gl merupakan model pembelajaran kontekstual, hal ini membuat pemahan siswa dalam memahami materi lebih lama, sehingga siswa mampu mengintegrasikan pengetahuan konsep materi biologi. Kemampuan berpikir kritis siswa dalam memahami materi biologi memiliki tujuan agar siswa mampu membuat kesimpulan dengan tepat dan tidak terjadi miskonsepsi pengetahuan dari materi biologi. Studi literatur pengaruh model pembelajaran GI terhadap kemampuan berpikir kritis dan aktivitas lisan siswa pada materi biologi yaitu, model GI berpengaruh terhadap kemampuan berpikir kritis siswa pada materi biologi dan model Gl berpengaruh terhadap aktivitas lisan siswa.

\section{RUJUKAN}

Aini, Z., Ramdani, A., \& Ahmad, R. (2018). Perbedaan Penguasaan Konsep Biologi dan Kemampuan Berpikir Kritis Siswa Kelas X Pada Penerapan Model Pembelajaran Kooperatif TIpe Group Investigation dan Guided Inquiry di MAN 1 Praya. JURNAL PIJAR MIPA, XIII(1), 19-23.

Anggis, E. V. (2018). Penggunaan Model Group Investigation Untuk Meningkatkan Berpikir Kritis Siswa Smp. Edubiotik: Jurnal Pendidikan, Biologi Dan Terapan, 3(02), 1-4. https://doi.org/10.33503/ebio.v3i02.94 
Aslahah, B. H. al, Susilo, H., \& Prasetyo, T. I. (2016). Pengaruh Strategi Pembelajaran Group Investigation (Gl) Terhadap Kemampuan Berpikir Kritis Siswa SMA Di Kota Malang. Journal Online UM, 5(564), 1-19. https://doi.org/10.4324/9781315853178

Asokawati, B. M., Widodo, A. T., \& Mursiti, S. (2018). Pengaruh model pembelajaran kooperatif terintegrasi investigasi terhadap hasil bealajar dan aktivitas siswa SMA. Jurnal Inovasi Pendidikan Kimia, 12(2), 2170-2178.

Bano, N. D. N., Supu, A., \& Lantik, V. (2019). Penerapan Model Number Head Together dan Group Investigation Untuk Meningkatkan Kemampuan Berpikir Kritis Siswa. Edufisika Jurnal Pendidikan Fisika, 4(Vol 4 No 2), 54-64.

Darmawanti, D. Y. (2017). Upaya Peningkatan Aktivitas Belajar dan Hasil Belajar Kognitif Pada Materi Sistem Pernapasan Manusia Melalui Model Pembelajaran Quantum teaching Siswa kelas XI IPA 1 SMA Muhammadiyah 7 Yogyakarta. Skripsi, 60.

Daud, F., \& Warti, D. (2011). Pengaruh Penerapan Model Pembelajaran Kooperatif Tipe Grup Investigasi Terhadap Aktivitas dan Hasil Belajar Siswa Kelas X SMA Negeri 1 Bajeng Pada Konsep Ekosistem. Bionature, 12(1), 45-52.

Fahriani, V. P., Wahyu, W., Setiawan, R., Hidayat, R., Karawang, U. S., \& Indonesia, U. P. (2019). Pengaruh Model Pembelajaran Kooperatif Tipe Group Investigation ( Mpkt G I ) Terhadap Kemampuan Berkomunikasi Pada Topik Titrasi AsamBasa. Dinamika Pendidikan, 12(2), 87-98.

Hapsari, D. P., Sudarisman, S., \& Marjono. (2012). Pengaruh Model Inkuiri Terbimbing dengan Diagram V (Vee) dalam Pembelajarann Biologi Terhadap Kemampuan Berpikir Kritis dan Hasil Belajar Siswa. Jurnal Pendidikan Biologi, 4(3), 16-28.

Hayani, F. (2017). Perbedaan Keterampilan Berpikir Kritis Siswa Pada Konsep Fungi Dengan Model Kooperatig Think Pair Share (TPS) dan Group Investigation (GI). Skripsi.

Insyasiska, D., Zubaidah, S., Susilo, H., Biologi, P., \& Malang, U. N. (2015). Pengaruh Project Based Learning Terhadap Motivasi Belajar, Kreativitas , Kemampuan Berpikir Kritis, Dan. Jurnal Pendidikan Biologi, 7(1).

Juwita, C. N., Samingan, \& Sarong, M. A. (2014). Penerapan Pembelajaran Kooperatif Student Teams Achievement Divisions (STAD) Berbasis Multimedia Terhadap Berpikir Kritis Siswa SMAN 1 Sakti Kabupaten Pidie Pada Materi Sistem Penapasan. Jurnal Biotik, 2(2), 83-87.

Linda. (2010). Upaya Meningkatkan Kemampuan Kognitif (C1-C4) Siswa Pada Materi Ekosistem Melalui Model Group Investigation Kelas X-7 di SMA N 2 Yogyakarta Tahun Ajaran 2009/2010. Skripsi.

Maula, D., Sri, T., \& Wulandari, H. (2018). Pengaruh Model Pembelajaran Kooperatif Tipe Group Investigation ( GI ) dengan Media Flash Card terhadap Kemampuan Berpikir Kritis Siswa SMP Effect of Cooperative Learning Model Type Group Investigation ( $\mathrm{Gl}$ ) With Flash Card Media to Critical Thinking Abi. Proceeding Biology Education Conferce, 15 (1), 317-323.

Murdiyani, I. (2012). Pembelajaran Biologi Menggunakan Metode E-Learning Berbasis Multiple Intelligences Pada Materi Sistem Gerak Manusia. Innovative Journal of Curriculum and Educational Technology, 1(1).

Nadiya, Rosdianto, H., \& Murdani, E. (2016). Penerapan Model Pembelajaran Group Investigation ( Gl ) untuk Meningkatkan Keterampilan Berpikir Kritis Siswa pada Materi Gerak Lurus Kelas X. Jurnal IImu Pendidikan Fisika, 1(2), 49-51. 
Nilasari, E., Djatmika, E. T., \& Santoso, A. (2016). Pengaruh Penggunaan Modul Pembelajaran Kontekstual Terhadap Hasil Belajar Siswa Kelas V Sekolah Dasar. Jurnal Pendidikan: Teori, Penelitian, Pengembangan, 1(7), 1399-1404.

Oktaviani, O., Jalmo, T., \& Marpaung, R. R. T. (2014). Pengaruh Pembelajaran Kooperatif Tipe Group Investigation (GI) Terhadap Kemampuan Berpikir Kritis Siswa. Jurnal Bioterdidik.

Palestina, S. M. F., Samingan, \& Apriana, E. (2014). Penerapan Pendekatan Pembelajaran Berbasis Masalah Terhadap Peningkatan Kemampuan Berpikir Kritis Pada Konsep Sistem Pernapasan Manusia. Jurnal Biotik, 2(1), 72.

Riani, E. D., Peniati, E., \& Supriyanto. (2017). Penerapan Model Group Investigation terhadap Kemampuan Bertanya Siswa Materi Sistem Regulasi. Journal of Biology Education, 6(2), 232-239. https://doi.org/10.15294/jbe.v6i2.19326

Rosiani, E., Parmin, \& Taufiq, M. (2020). Coopeerative Learning Model Of Group Investigation Type On Students Critical Thinking Skill and Scientific Communication Skills. Unnes Science Education J, 9(1), 392-402.

Santyasa, I. W., Kanca, I. N., Warpala, I. W. S., \& Sudarma, I. K. (2019). Group Investigation and Explicit learning Models in Learning Physics at Senior High Schools. Jurnal Penelitian \& Pengembangan Pendidikan Fisika, 5(2), 203-216. https://doi.org/10.21009/1.05216

Surya, E., Khairil, \& Razali. (2014). Penerapan Pembelajaran Berbasis Masalah (PBL) Untuk Meningkatkan Kemampuan Berpikir Kritis Siswa Pada Konsep Sistem Pernapasan Manusia Di SMA Negeri 11 Banda Aceh. Jurnal Edubio Tropika, 2(April), 121-186.

Suswina, M. (2016). Hasil Validitas Pengembangan Bahan Ajar Bergambar Disertai Peta Konsep Untuk Pembelajaran Biologi Sma Semester 1 Kelas Xi. Ta'dib, 14(1). https://doi.org/10.31958/jt.v14i1.196

Trismanita, S., Jalmo, T., \& Marpaung, R. R. T. (2014). Pengaruh Penerapan Model Pembelajaran Group Investigation Terhadap Aktivitas dan Hasil Belajar Siswa. Jurnal Bioterdidik.

Wang, carol chungfeng, Andre, K., \& Greenwood, kenneth mark. (2015). Nurse Education Today Chinese students studying at Australian universities with speci fi c reference to nursing students: A narrative literature review. Nurse Education Today, 35(4), 609-619. https://doi.org/10.1016/j.nedt.2014.12.005

Wibowo, S. (2011). Perbandingan Hasil Belajar Biologi Dengan Menggunakan Metode Pembelajaran Cooperative learning Tipe Group Investigation (GI) dan Think Pair Share (TPS). Skripsi, 18-19.

Wijaya, E. Y., Sudjimat, D. A., \& Nyoto, A. (2016). Transformasi Pendidikan Abad 21 Sebagai Tuntutan Pengembangan Sumber Daya Manusia di Era Global. Jurnal Pendidikan, 1, 263-278.

Wijayanti, W., Herlambang, S., \& K, M. S. (2013). Pengaruh model pembelajaran group investigation (gi) terhadap kemampuan berpikir kritis siswa kelas $\mathrm{x}$ sma negeri 1 mejayan kabupaten madiun. Jurnal Pendidikan Geografi Universitas Negeri Malang, 3(1), 14.

Winarni, Santosa, S., \& Ramli, M. (2016). Penerapan Model Discovery Learning untuk Meningkatkan Oral Activities Siswa SMA Discovery Learning Model for Enhancing Oral Activities of High School Student. Bioedukasi: Jurnal Pendidikan Biologi, 9(2), 55-61.

Yuniasti, A., \& Wulandari, R. (2014). Pengaruh Pembelajaran Kooperatiftipe Student Team Achievement Division (STAD) dan Group Investigation (GI) Ditinjau dari Aktivitas Belajar. Jurnal Pena Sains, 1(2), 36-45. 